\title{
Developing a Mentorship Program in Higher Education Institutions ${ }^{1}$
}

\author{
Jonathan M. Orsini, Matthew P. Benge, and Hannah S. Carter ${ }^{2}$
}

\section{Introduction}

Higher education institutions are currently tackling a growing number of organizational challenges that have forced departments to evolve their business practices. Administrators are faced with the need for more diverse programs, which require facilities, faculty, and services, and must decide whether to develop talent internally or recruit new, qualified candidates (Kutchner \& Kleschick, 2016). Given the great cost of faculty searches and the perceived diminishing availability of talented applicants, it is imperative that administrators understand the importance and value of mentoring relationships to fill needs with qualified candidates in higher education institutions. However, formal mentoring programs have been slow to develop in higher education institutions. This publication defines mentorship, explains the value of mentorship, and describes how mentoring programs can be established.

\section{Defining Mentorship}

One of the issues impacting the development of effective mentorship practices has been the long-term lack of a concise, accepted definition across disciplines (Jacobi, 1991). However, reviews of the literature provide five general components and fifteen functions for which there is strong agreement.

\section{General Components and Functions of Mentorship (Jacobi, 1991)}

1. Mentoring relationships are usually focused on achievement in which a mentor provides assistance and support for a protégé. This support is usually academic or professional and addresses longer-term career goals. This relationship may or may not include formal authority.

2. Mentoring includes any or all of the following components:

- Emotional and psychological support

- Assistance with career development

- Role-modeling

3. Both the mentor and protégé should benefit (either emotionally or materially) from the relationship.

4. Mentoring relationships are personal and require direct interactions on a regular basis. While these relationships are not duration-dependent and do not require great intimacy or intensity, they should involve the sharing of information (personal or professional) not available in the public domain.

1. This document is AEC665, one of a series of the Department of Agricultural Education and Communication, UF/IFAS Extension. Original publication date April 2019. Visit the EDIS website at https://edis.ifas.ufl.edu for the currently supported version of this publication.

2. Jonathan M. Orsini, PhD student; Matthew P. Benge, assistant professor; and Hannah S. Carter, associate professor; Department of Agricultural Education and Communication; UF/IFAS Extension, Gainesville, FL 32611.

The Institute of Food and Agricultural Sciences (IFAS) is an Equal Opportunity Institution authorized to provide research, educational information and other services

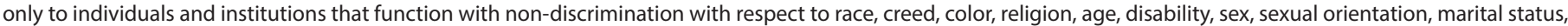

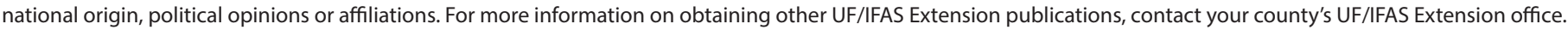
U.S. Department of Agriculture, UF/IFAS Extension Service, University of Florida, IFAS, Florida A \& M University Cooperative Extension Program, and Boards of County Commissioners Cooperating. Nick T. Place, dean for UF/IFAS Extension. 
5. Mentors should be significantly more experienced, influential, and have more achievements than their protégé within an organizational or environmental context.

\section{Functions (Tubb-Warbington, 2011)}

- Role-modeling of appropriate faculty member attitudes, values, and behaviors, including building professional networks.

- Direct teaching of academic skills and norms, including the unwritten rules of a department, college, and university.

- Providing research-related guidance, including program management, managing data, and publishing opportunities.

- Offering the mentee a collaborative role in research, including co-authoring articles, contributing to research design, and selecting journals for publishing opportunities.

- Providing advice on the benefits of serving on committees, strategies for work-life balance, and the tenure process.

- Reviewing work and career progress, including teaching and research goals.

- Advocating for the mentee's success through networking and facilitating, and providing opportunities for career advancement and acclaim.

- Providing encouragement through professional, emotional, and psychological support.

\section{Benefits of Mentorship}

Research shows that mentoring has many benefits for the mentor, protégé, and the organization. The organization typically benefits from higher levels of retention, greater leadership competency overall, and having leaders ready internally, which prevents the need for costly faculty searches. Mentees often work better in teams, act as mentors themselves, and generally feel valued by the organization. Additionally, the mentoring process provides mentees with increased social capital or networks that they would not otherwise have access to (Kahle-Piasecki \& Doles, 2015). It has been theorized that this socialization for faculty who receive formal mentoring in academia is responsible for mentees being more productive than researchers without mentors (Muschallik \& Pull, 2016). More and more, senior leadership attribute much of their success to mentoring they received and identify the following benefits (Zachary \& Fischler, 2010):

- Stimulates relationships throughout the organization

- Creates connections between people

- Promotes career and leadership development

- Encourages big-picture thinking

- Supports diversity efforts

- Provides a different way to manage knowledge within the organization

- Facilitates the growth and development of potential leaders

- Aids in recruitment and retention

- Improves technical knowledge

There are a number of reasons why formal mentorship programs have been slow to develop in academia. First, many in this field presume that faculty are well-prepared for their careers. Second, faculty are not generally interested in finding a mentor, either because of time constraints or because they do not see the value inherent to the process. Third, the traditional organizational structure of academia, with the traditional three-rung tenure track, prevents faculty from seeing the opportunities and benefits of a mentoring relationship. Finally, administrative leadership and other faculty are traditionally followers of the "sink or swim" approach, and most value faculty who can "figure it out on their own" (de Janasz \& Sullivan, 2004).

\section{Developing a Mentorship Program}

Research has shown that in order for organizations to achieve success and efficiency they must engage the knowledge, skills, and commitment of their employees, which can be accomplished by linking people's strategies to the greater organizational mission. Many higher education mentorship programs fail to develop clear goals at the individual level or make connections to beneficial outcomes of mentoring relationships. In order for higher education institutions to create effective faculty mentoring, leadership must provide a multi-dimensional framework to support the development, implementation, and assessment of these programs (Baker, 2015). 


\begin{tabular}{|c|c|c|}
\hline Framework & Person Responsible & Process \\
\hline Vertical Alignment & $\begin{array}{l}\text { Senior } \\
\text { Or } \\
\text { Executive Leadership of } \\
\text { Academic Unit }\end{array}$ & $\begin{array}{l}\text { - Focuses at the macro level } \\
\text { - Connects people's strategy and organizational goals } \\
\text { - Develops screening and training processes for } \\
\text { mentors } \\
\text { - Provides specific guidance on how the relationship } \\
\text { should evolve } \\
\text { - Guidelines should be shared and specific goals set } \\
\text { for the outcome of the mentoring relationship } \\
\text { - Administration must link the individual goals from } \\
\text { the mentorship program to larger, clearly articulated } \\
\text { department, college, or institutional goals }\end{array}$ \\
\hline Horizontal Alignment & $\begin{array}{l}\text { Human Resources working with Senior or } \\
\text { Executive Leadership }\end{array}$ & $\begin{array}{l}\text { - HR policies are developed and clearly articulated to } \\
\text { employees } \\
\text { - Different employee groups (faculty, staff, etc.) will } \\
\text { require clear and tailored program guidelines } \\
\text { - Clear and measurable goals are set } \\
\text { - Define measures of success, expectations of partici- } \\
\text { pation, and individual responsibilities } \\
\text { - The context of the department/college/division } \\
\text { should also be taken into consideration when } \\
\text { designing these HR policies }\end{array}$ \\
\hline Implementation & Mentorship Program Coordinator & $\begin{array}{l}\text { - The action step of the framework and alignment } \\
\text { process } \\
\text { - Imperative to assign a top administrator to oversee, } \\
\text { design, and implement mentoring programs in an } \\
\text { organization } \\
\text { - Evaluation of effective implementation is imperative } \\
\text { to allow for adjusting goals and determining new } \\
\text { desired outcomes } \\
\text { - Regular assessment of the mentees, mentors, and } \\
\text { overall program will be key to maintaining vertical } \\
\text { and horizontal alignment and sustaining an effective } \\
\text { mentoring program }\end{array}$ \\
\hline
\end{tabular}

In addition, many studies have shown that the following factors are typically associated with highly effective mentoring programs in higher education (Fountain and Newcomer, 2016):

- Clearly stated and visible goals and support frequently communicated from executive leadership to the mentorship program coordinator and to faculty.
- Continuous program evaluation that includes short and long-term measurable goals, with frequent opportunities for review and assessment.

- A design that instills mentoring as a core institution cultural value that aligns with organizational goals.

- A program that mandates regular meetings and communication between participants. 
- Intentional matching of mentors and mentees for compatibility based on personality, discipline, and work or learning styles.

- Orientation and continual mentorship training for mentors and mentees that lays out specific goals, program expectations, and tips for building relationships.

\section{Conclusion}

Mentoring relationships foster professional, psychological, and social benefits for those involved (APA, 2006). At institutions of higher learning, both mentors and mentees report that mentoring helps with teaching, research, career planning and that visible support for mentoring is critical to participation (Fountain \& Newcomer, 2016). As research continues in the mentoring field, more focus will be placed on the connection between mentorship and organizational outcomes, which should be extremely relevant to university leadership and administration in the years to come. As institutions of higher learning continue to evolve in the face of growing competition and reduced state and federal funding, mentoring programs should be considered a priority to provide support and professional guidance to the growing number of adjunct, part-time, and junior faculty to improve organizational outcomes.

\section{References}

American Psychological Association. (2006). Introduction to Mentoring: A Guide for Mentors and Mentees. http:// www.apa.org/education/grad/mentoring.aspx.

Baker, V. L. (2015). People Strategy in Human Resources: Lessons for Mentoring in Higher Education. Mentoring \& Tutoring: Partnership in Learning, 23(1), 6-18.

de Janasz, S. C., \& Sullivan, S. E. (2004). Multiple mentoring in academe: Developing the professorial network. Journal of Vocational Behavior, 64(Careers in Academe: A Special Issue of the Journal of Vocational Behavior), 263-283.

doi:10.1016/j.jvb.2002.07.001

Fountain, J., \& Newcomer, K. E. (2016). Developing and Sustaining Effective Faculty Mentoring Programs. Journal of Public Affairs Education, 22(4), 483-506.

Jacobi, M. (1991). Mentoring and Undergraduate Academic Success: A Literature Review. Review of Educational Research,61(4), 505-532. http://www.jstor.org/stable/1170575.
Kahle-Piasecki, L., \& Doles, S. (2015). A Comparison of Mentoring in Higher Education and Fortune 1000 Companies: Practices to Apply in a Global Context. Journal of Higher Education Theory \& Practice, 15(5), 74-79.

Kutchner, W., \& Kleschick, P. (2016). Mentoring in Higher Education Administration. College \& University, 91(4), 41-46.

Muschallik, J. and Pull, K. (2016). Mentoring in Higher Education: Does it Enhance Mentee's Research Productivity? Education Economics, 24(2), 210-223.

Tubb-Warbington, C. (2011) A Guide to Mentoring Faculty. University of Central Arkansas Center for Teaching and Excellence. http://uca.edu/cte/files/2011/06/MentoringFinal-Draft-5.14.pdf.

Zachary, L. J., and L. A. Fischler, L. A. (2010). Those who lead, mentor. $T+D$, (3). 52 . 